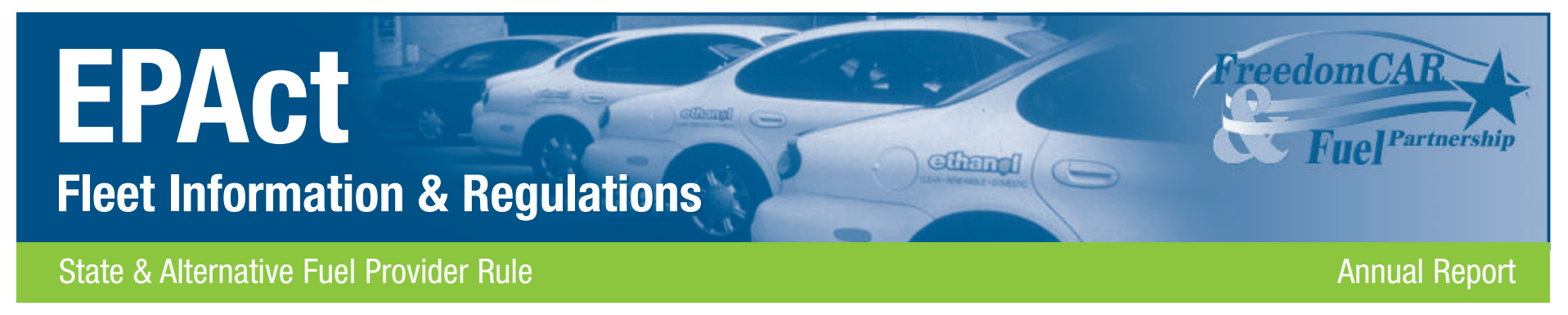

\title{
Activities and Accomplishments in MY 2006/FY 2007
}

In model year (MY) 2006, covered state and alternative fuel provider (S\&FP) fleets that report to the U.S. Department of Energy (DOE) complied with Energy Policy Act of 1992 (EPAct) fleet provisions (10 CFR Part 490) by:

- Acquiring 12,798 alternative fuel vehicles (AFVs).

- Earning more than 2,900 biodiesel credits.

- Purchasing almost 940 AFV credits.

Results published in this report show that fleets continue to successfully meet their EPAct requirements by using alternative fuel technologies. As in previous years, DOE saw increases in biodiesel use and the number of new light-duty vehicles (LDVs) acquired, as fleets appear to be buying a higher proportion of new vehicles. Ethanolcapable flexible fuel vehicles (FFVs) purchased by state fleets totaled 11,531, while alternative fuel providers acquired 526 FFVs. Additionally, the use of credits declined-from a high of 1,312 in 2004 to 933 in 2006. For MY 2006 reporting highlights, see Table 1.

\section{Status of Covered Fleets}

In MY 2006, all 318 entities* covered under the S\&FP Rule reported to DOE. Almost $100 \%$ of covered fleets are in full compliance. These compliance requirements include acquiring light-duty AFVs, purchasing credits from other fleets, employing banked credits, and using biodiesel.

\section{Vehicle Acquisitions}

AFV acquisition is the predominant method of compliance. Under S\&FP regulations, 75\% of new covered LDVs acquired by state fleets must be AFVs, while $90 \%$ of LDVs acquired by alternative fuel providers must be AFVs. AFV acquisition requirements are determined by multiplying a fleet's number of newly acquired, non-

\begin{tabular}{|l|r|}
\hline \multicolumn{2}{|c|}{ Table 1. MY 2006 Highlights } \\
\hline AFVs Purchased & 12,798 \\
\hline Banked Credits Used & 2,382 \\
\hline Credits Purchased & 933 \\
\hline Biodiesel Used (B100) & 5.2 million gallons \\
\hline Biodiesel Credits Awarded & 2,928 \\
\hline
\end{tabular}

excluded LDVs by the applicable percentages. In MY 2006, the number of covered LDV acquisitions was 19,647 , an $18 \%$ increase from the previous year.

To meet this requirement, covered fleets acquired 12,798 AFVs in MY 2006-a 27\% increase from the previous year. State fleets acquired 11,832 vehicles, the vast majority of them FFVs.

The MY 2006 requirement for fuel provider fleets was 3,794 AFVs-202 more vehicles than MY 2005's requirement of 3,592 vehicles. The actual number of AFVs acquired was 966 . As in previous years, fuel providers met their AFV requirement primarily through the use of banked credits and biodiesel. For AFV acquisitions by state and alternative fuel provider fleets, see Figure 1. For the breakdown on the types of AFVs purchased in MY 2006, see Table 2.

\section{Credit Use and Purchase}

Covered fleets earn bankable credits by acquiring more AFVs than required. In MY 2006, fleets exceeded their AFV requirements and earned 2,928 credits. These credits can be banked for future compliance or sold to other

* Some entities represent one agency or business; others constitute fleet operations for an entire state. 


\begin{tabular}{|l|c|}
\hline \multicolumn{2}{|c|}{ Table 2. AFVs Acquired in MY 2006} \\
\hline Light-Duty Sedans & 6,397 \\
\hline Light-Duty Pickups & 3,255 \\
\hline Minivans & 2,412 \\
\hline Sport Utility Vehicles & 626 \\
\hline Medium-Duty Trucks & 96 \\
\hline Heavy-Duty Trucks & 6 \\
\hline Buses & 6 \\
\hline
\end{tabular}

Figure 1. AFVs Acquired in MY 2006

(by Fleet Type)

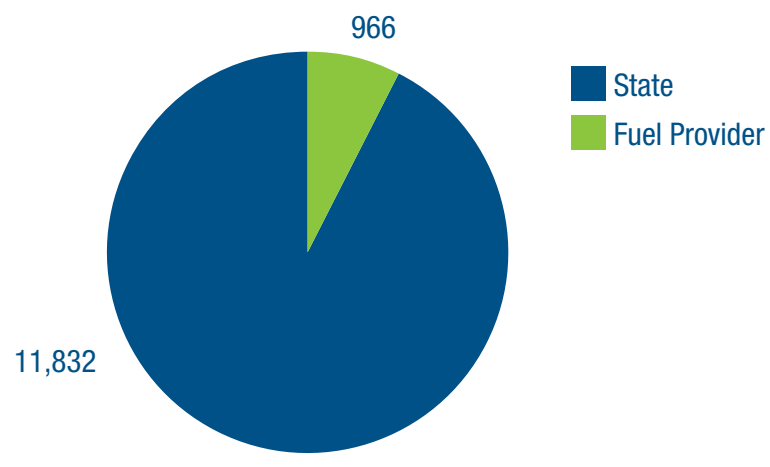

Figure 2.

Credits Purchased Annually

(by Model Year)

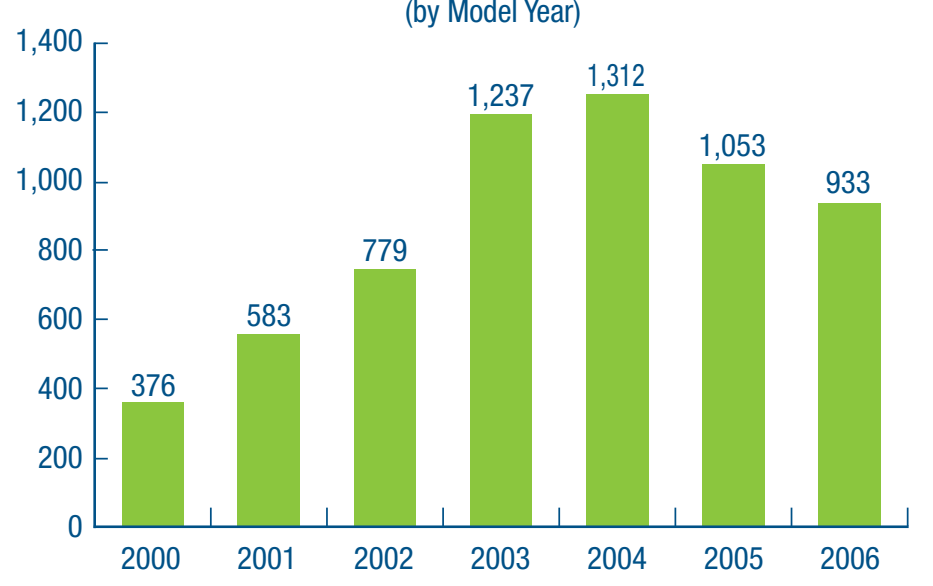

Figure 3.

Annual Biodiesel Fuel Use

(B100 in Gallons)

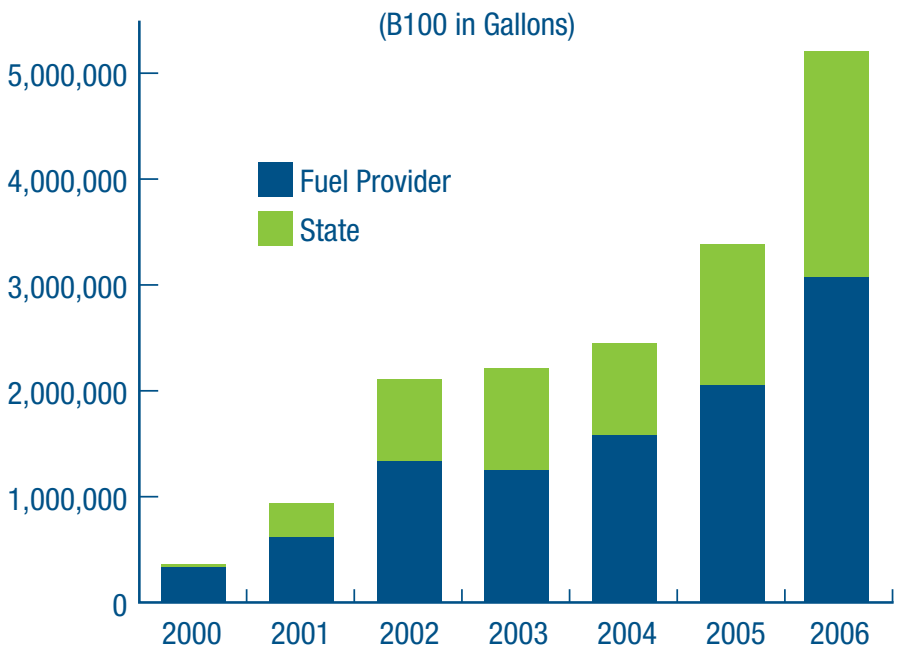

* For more information on how biodiesel credits are calculated, download "Reporting Biodiesel Fuel Use Credits" from the EPAct website at www.eere.energy.gov/vehiclesandfuels/epact/pdfs/ biodiesel_guidance.pdf. 


\section{Fleet Fuel Preferences}

In MY 2006, FFVs that run on E85 accounted for $94 \%$ of newly acquired AFVs. Vehicles powered by CNG and liquefied natural gas came in second at $4 \%$. Liquefied petroleum gas (LPG) and electric vehicles made up the remaining $2 \%$. This year's reported vehicle acquisitions continue the trend to FFVs and away from gaseous fuel vehicles. This is to be expected, however, since gaseous fuel vehicle offerings were limited in MY 2006.

Of the 12,057 FFVs acquired in MY 2006, 11,531 were purchased by state fleets. More and more fleets are using E85 and installing onsite fueling infrastructure in response to local mandates requiring them to use E85 and other alternative fuels in state vehicles. According to DOE's Alternative Fuels Data Center, the total number of E85 fueling sites in the United States is up 51\% since 2005 , bringing the total to 1,152 stations*. Thirty-one E85 fueling sites are owned by state government entities.

FFV acquisitions by alternative fuel provider fleets also increased in MY 2006. These fleets purchased 526 FFVs, up from 304 in MY 2005. DOE expects this trend to continue due to limited AFV offerings that operate on propane or natural gas and an increasing number of E85 refueling stations.

${ }^{*}$ As of June 2007.

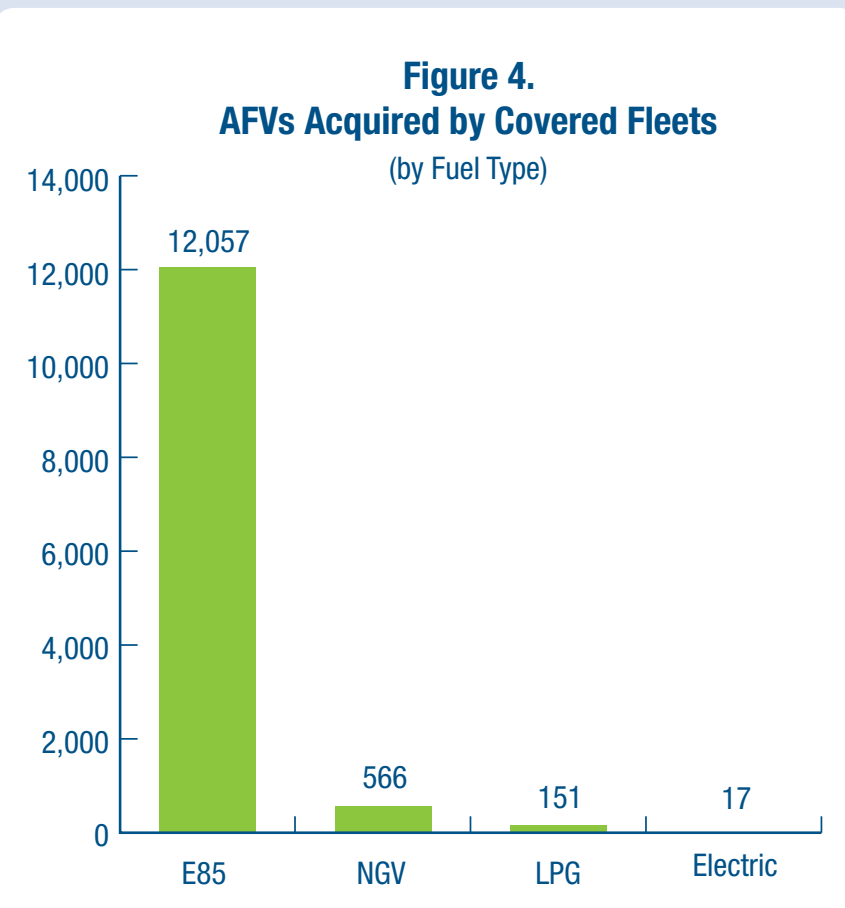

\section{Exemptions}

Overall, exemptions* represented a small percentage of fleet activity in MY 2006. This year, fleets received 1,268 vehicle exemptions - a 24\% increase from the 1,022 exemptions granted in MY 2005. This increase can be attributed to the discontinuation of full-size, compressed natural gas (CNG) pickups by original equipment manufacturers in MY 2006, leaving only one CNG light-duty vehicle (the Honda Civic GX) on the market. The lack of available CNG vehicles directly impacts many alternative fuel provider fleets, which have historically had the largest portions of CNG AFVs in their fleets.

\section{Program Activities and Accomplishments}

In fiscal year (FY) 2007, DOE continued to work with fleets to increase the number of AFVs acquired and to expand the use of alternative fuels. Efforts included communications with covered fleets and presentations at workshops and conferences.

\section{Communications, Workshops, and Presentations}

On March 20, 2007, DOE issued its final rule on the new Alternative Compliance option, which allows covered fleets to apply for a waiver from their AFV acquisition requirements to employ petroleum consumption reduction measures. To help fleets understand this new option, DOE developed the following documents and tools:

- Alternative Compliance: Guidelines for Preparing and Submitting a Waiver Request and Other

Documentation Requirements (www.eere.energy.gov/ vehiclesandfuels/epact/pdfs/alt_comp_guide.pdf) This guidance document details all aspects of the new option.

- Alternative Compliance Planning Tool (www.eere. energy.gov/vehiclesandfuels/epact/state/acp_tool)_ This interactive online tool helps fleets determine their petroleum reduction requirement and create a plan for meeting it.

- Alternative Compliance Tutorial (www.eere.energy. gov/vehiclesandfuels/epact/state/alt_tutorial.html) This five-module, electronic training series breaks the guidance document into easy-to-understand pieces.

* Exemptions are detailed in the addendum to Documentation Requirements for Exemption Requests, which is available on the EPAct Web site at www.eere.energy.gov/vehiclesandfuels/epact/pdfs/ exemption_addendum2.pdf. 
In addition, DOE hosted workshops in four U.S. cities to raise fleet awareness of E85 and increase the use of the fuel in state FFVs. The workshops, which were organized and presented by the American Lung Association of Minnesota, were held in Madison, Wis.; Raleigh, N.C.; Lansing, Mich.; and Des Moines, Iowa. Attendance ranged from 50 to 100 state and industry executives per location, and participant feedback for the workshops was positive.

Finally, DOE presented materials on alternative compliance at several fleet conferences in FY 2007. These include events hosted by the National Association of Fleet Administrators and the Edison Electric Institute Fleet Management and Policy Committee Meeting. DOE also plans to exhibit and present at the National Conference of State Fleet Administrators in Hershey, Penn., in the fall.

In FY 2007, DOE sent covered fleets announcements and reporting reminders. In addition, e-mails and letters were sent to covered fleets that failed to file timely reports. Failure to submit a timely report is a violation

\section{What Is EPAct?}

The Energy Policy Act of 1992 (EPAct) was passed by Congress to reduce the nation's dependence on imported petroleum. Provisions of EPAct require certain fleets to purchase AFVs. DOE administers these requirements through its State \& Fuel Provider Rule, Federal Fleet Requirements, and Alternative Fuel Designation Authority.

For more information, visit www.eere.energy.gov/vehiclesandfuels/ epact, or call the Regulatory Information Line at 202-586-9171. of EPAct requirements. Fleets with credit deficiencies were also sent letters that told them to resolve deficiencies by purchasing credits.

\section{Future Activities}

Looking ahead, DOE will update the S\&FP Web site to include detailed information on the Alternative Compliance option, develop additional materials to help fleets find and build fueling infrastructure, and produce fact sheets detailing the successful AFV programs of state and alternative fuel provider fleets. In addition, DOE will continue to improve its process for reviewing Alternative Compliance waiver applications and notifying fleets of their acceptance or denial into the program. DOE will also update Alternative Compliance tools and documents to reflect lessons learned during the first year of the new option.

\section{Conclusion}

In MY 2006, covered fleets were successful in their efforts to comply with S\&FP requirements. As part of their compliance efforts, covered fleets acquired more than 12,700 AFVs and consumed 5.2 million gallons of biodiesel (B100). All fleets have reported, and the few fleets with deficiencies are resolving them. DOE has maintained its outreach efforts by delivering announcements and reminders to fleets, hosting workshops, presenting at conferences, and developing documents and tools detailing the new Alternative Compliance option.
Sponsored by the U.S. Department of Energy

Energy Efficiency and Renewable Energy

FreedomCAR and Vehicle Technologies Program

For more information contact: EERE Information Center 1-877-EERE-INF (1-877-337-3463) www.eere.energy.gov

Prepared by the National Renewable Energy Laboratory (NREL) NREL is a U.S. Department of Energy National Laboratory Operated by Midwest Research Institute $•$ Battelle

\begin{abstract}
A Strong Energy Portfolio for a Strong America
Energy efficiency and clean, renewable energy will mean a stronger economy, a cleaner environment, and greater energy independence for America. Working with a wide array of state, community, industry, and university partners, the U.S. Department of Energy's Office of Energy Efficiency and Renewable Energy invests in a diverse portfolio of energy technologies.
\end{abstract}

DOE/GO-102007-2438 • August 2007

Printed with a renewable-source ink on paper containing at least $50 \%$ wastepaper, including $10 \%$ postconsumer waste 